\title{
Implementation of Transformative Learning Theory In Improving The Metacognitive Knowledge of Physics Student of Institute of Teachers' Education
}

\author{
Mara Bangun Harahap \\ Physics Department, \\ Faculty of Mathematics and Natural Sciences, \\ State University of Medan, \\ Medan, Indonesia \\ Corresponding author: marabharahap@gmail.com
}

\begin{abstract}
In this paper discussed how to improve the metacognitive knowledge of physics student of Institute of Teachers' Education (Lembaga Pendidikan Tenaga Kependidikan: LPTK) using transformative learning theory. Physics student of LPTK have difficulty increase metacognitive knowledge of physics, due to the difficulty in transforming the concept. In this paper described how to facilitate this change (transformation concept) use of transformative learning theory. The discussion in this paper provide input for faculty and students in metacognitive learning. Discussions focused on developing a theoretical model of learning based on the theory of transformative learning in improving the metacognitive knowledge of physics students of LPTK.
\end{abstract}

Keywords: metacognitive knowledge, metacognitive learning, transformative learning theory, transforming the concept.

\section{INTRODUCTION}

The main competence of the author in carrying out the task of three task (tridarma) in S1 program majoring in physics in Faculty of Mathematics and Natural Sciences, State University of Medan is lecturer quanntum physics course. In addition, the authors have the competence to develop effective learning models in achieving competence, in accordance with research dissertation writer [14] relating to the development of Social-Cognitive Constructivist Learning Model and research writers with Amdani who developed the learning model Approach Applied Applied Approach: AA) based on Systematic Solving Problem (PSSS) ([16];[15];[8]). The subjects of quantum physics in s1 program and of course in s2 and s3 program of universities in Indonesia even in the world are hard to learn material (according to teaching experience and research result of writer with Amdani ([14]; [8] ) and according to Morrison [13].. Morrison [13] states there are three reasons why studying quantum physics is more difficult than studying classical physics. First, Man grows in and becomes accustomed to the macroscopic world. Thus, when studying quantum physics, the real is the most powerful theory for the microscopic world (atomic and subatomic), people often experience opposition in understanding the quantum phenomena which is distinctly different from the classic phenomena commonly used in everyday life. Secondly, quantum physics works in one-tier territory above reality, that quantum physics is more abstract than classical physics. Third, quantum physics is inherently is mathematical, meaning that mathematics is the language of quantum physics. Thus, without mastering mathematics as a language of quantum physics and unskillfully applying the language in solving the problems of quantum systems, it would be difficult to understand quantum physics.

Based on the experience of teaching and the research result of the author ([14], [15], [16], [17]) revealed that the main problem of students in understanding the concept of quantum physics is the difficulty of the students change the conception of classical physics into a conception of quantum physics that is scientific conception, so the metacognitive knowledge of students is low. In fact, often the classical conception of physics mixes with the mistaken conception of quantum physics. This student difficulty is in line with Morrison's first factor above, ie the student grows in and becomes accustomed to the macroscopic world. Thus, when studying quantum physics, which is clearly the most powerful theory for the microscopic world (atomic and subatomic), students often experience a contradiction in understanding the quantum phenomena distinctly different from those of classical physics commonly found in everyday life . In addition, based on the experiences and research results of researchers ([16]; [15]; [8]) in teaching students, in line with the third factor about the difficulty of studying quantum physics put forward Morrison in Above, the ability factor of students to apply mathematics as the language of quantum physics in solving the problems of simple quantum physics system becomes the factor causing the difficulties of students to understand quantum physics.

With regard to the problem of applying mathematics in physics, the ability to apply mathematics in solving quantum physics problems is the ability to solve physics problems that have been categorized as formal problems of physics according 
to Piaget's cognitive development theory [6]. This ability is called the formal ability to study quantum physics. Based on that fact, we have compiled a theoretical learning model that implements transformative learning theory in increasing the metacognitive knowledge of students in quantum physics lectures. The theoretical learning model is called the cognitivesocial learning model based on transformative learning theory.

\section{LITERATURE REVIEW}

2.1 The Metacognitive Knowledge of Physics Student of Institute of Teachers' Education

The mastery of metacognitive knowledge, influenced by the change of conception. There are seven issues that can be identified from the results of research on the use of teaching and learning activities that promote the conversion of conception [3],. which will lead to mastery of metacognitive knowledge. First, it is difficult for students to change their existing ideas. Second, cognitive conflicts and events that do not conform may not result in the conversion of conception, which results in the ease of mastering metacognitive knowledge. Third, many learners who have modified their ideas in teaching in the classroom, perhaps resuming his original idea in school settings a few months later. Fourth, the concepts of teachers/ educators can influence the changing conception occurs, if any. Fifth, the order of teaching activity is still debated. Sixth, the study of changing conceptions of teaching to illuminate mismatch (mismatches) in science education between what we know about how students learn, on the one hand, and our classrooms, schools and education systems in the practice of science, on the other hand. The seventh or last, another factor that has to be clarified (illuminated) on the sale situation changing conception is the kind of science that is taught in the classroom.

\subsection{Model of Teaching}

At the first Aisteel seminar of 2016, the author has developed a learning model aimed at improving conceptual knowledge [17]. In this section, a learning model is developed that is expected to effectively increase metacognitive knowledge. Model development is done in the same way as the development of models for the improvement of conceptual knowledge. To be more clear, re-elaborated on the same rough development here. Based on a review of literature in the form of research: $[1,7,21,19,23,4,13,20,5,18]$, it turns learning model proposed development is a relatively new model of learning, which are not studied in Indonesia and even in foreign countries. Novelty which meant the researchers are no previous studies that develop models for effective learning to enhance and scientific conceptions and formal capabilities of students in learning quantum physics. Learning model developed from the results of research on the theoretical basis of learning and learning based on constructivism. The cornerstone of the theory of constructivism learning model is based on Piaget (called cognitive constructivism) and Vygotsky (called social constructivism) [3,12], as well as transformative learning theory. Preparation of the learning model based on the "shape" model of learning by $[2,4]$ as follows.

\section{Cognitive Constructivist Learning Model-Social Based Transformative Learning Theory}

SYNTAX: The model consists of four phases. The first phase is the phase invitational, the phase of its curious learners, by creating a situation that raises a question mark and inviting disclosure preconceptions learners. In this phase learners conception designed disclosure by filing a written or oral questions about the events or phenomena that can later be experimented by learners in groups or demonstrated by the teacher. In the second phase, activities of data collection, which is required for testing the concept that has been proposed to learners of events and /or phenomena in question in the first phase. Learner activities carried out by the group is an experiment. However, if the equipment and facilities available in the laboratory experiment is not sufficient, then selected the demonstration activities. In these experiments the learners check explanation (conception) that have been advanced in the first phase. At this stage the possibility of a conflict of cognitive and self-regulation (based on cognitive constructivist view). The second phase termed the exploration phase. In the second phase is also already happening collaborative learning (corresponding view of the social constructivist), that is, when a small group (experimental) they have started negotiating the conception of each, both conceptions that have been raised before the experiment and a new conception after checking experimentally turned out conception initially not accurate. The third phase is the phase of submission of explanation and solutions as well as discussions. In the third phase, the learning process is dominated by collaborative learning. Learners in this phase wasasked to express his conception of events or phenomena that prompted the first phase of the classes. Act as a class discussion of each conception disclosure. Collaborative learning environment take precedence and be kept consistent throughout the discussion. How that may be used is to declare to the learners that the discussion is not intended to seek the most appropriate response, but rather is to establish interpersonal communication, ie by observing or interpret answers each learner involved in class discussions. Everyone has the right and must be filed (proposed) conception. If the answer put forward in answering the question in the first phase is different from the test results through experiments or demonstrations during the second phase, then the learner concerned should be able to ask explanation and solutions to the differences in the class discussion. Expected in the third phase of construction of a new idea has occurred.The fourth phase is the phase retrieval action. The process of constructing a new look or a new conception on the third phase will prepare learners to take action on what they have learned. Least learners should be able to make decisions about still wearing the old conception or conception should change radically, and the risk must implement the new conception on any events and other phenomena related to those asked in the first phase. The action taken by the learner (change of conception or not) can be monitored by the answer on the incidence and/or other related phenomena, in the next lesson. For teachers, the fourth phase is the phase of determining whether teachers should provide further clues to the problems encountered in the classroom or not. 
Quantum physics problem solving methods (formal capability) used methods Systematic Problem Resolution (PSSS) [22]. The problem-solving method includes steps: ANALYSIS, PLAN, and ASSESSMENT COMPLETION. In step analysis conducted activities: Read the question carefully; Make a scheme or an image (which consists of: Noting the provisions given in the scheme and asked and Recording units and dimensions); Estimating answers (sign, magnitude, and its unit); Dividing the problem into smaller problems that can be solved; and make assumptions if necessary. In step PLANS do activities: Start with the amount sought/ask; Finding relationships (equations), which contains the amount of it (which consists of: Looking for a relationship that includes the amount given as well Combining these relations to reach a settlement); Noting the requirements for entry into force of those relationships; Develop remedy. In step COMPLETION do activities: Perform mathematical transformation (which consists of the following activities: Changing the general relations in a special relationship to the matter and Changing units and dimensions into the same system); Calculating to obtain answers; Examination of the terms of enforceability. In step ASSESSMENT do activities: Checks if the answer in line with forecasts and reality; Check if each part has been completed; Writing answers and final conclusions. In this research, a cognitive constructivist learning model-based social problem-solving method systematically. Learning Model Constructivist Cognitive-Based Social Method Resolution Problem Systematic is a learning model that embraces the view constructivism cognitive and social and contains four phases of activities, namely: Invitational, Exploration, Filing explanation and solution as well as the retrieval action and using methods Completion Problem Systematic and finish formal questions of quantum physics. Mezirow transformative learning theory used in each phase to change the conception (see for example: [9]). Based on the theory Mezirow, shifting paradigm / perspective transformation is the result of several conditions and processes: an activating event that exposes the limitations of a student's current knowledge/approach; opportunities for the student to identify and articulate the underlying assumpti ons in the student's current knowledge/approach; critical self-reflection as the student considers where these underlying assumptions came from, how these assumptions influenced or limited understanding; critical discourse with other students and the instructor as the group examines alternative ideas and approaches; opportunities to test and apply new perspectives [11].

\section{DISCUSSION}

By applying the theory of transformative learning in the phases of the learning model that builds on the framework of cognitive and social constructivist theory, suspected would happen alteration mistaken conceptual knowledge (misconceptions) into a true conceptual knowledge. Based on the theory Mezirow, shifting paradigm/ perspective transformation is the result of several conditions and processes: an activating event that exposes the limitations of a student's current knowledge/approach; opportunities for the student to identify and articulate the underlying assumpti ons in the student's current knowledge/approach; critical self-reflection as the student considers where these underlying assumptions came from, how these assumptions influenced or limited understanding; critical discourse with other students and the instructor as the group examines alternative ideas and approaches; opportunities to test and apply new perspectives [11].

\section{CONCLUSIONS}

Increased learner metacognitive knowledge is expected to occur as a result of concept transformation. In this paper, developed a theoretical model of learning. Learning model was developed based on the theory of constructivism and transformative learning theory. Physics student of $L P T K$ have difficulty increase metacognitive knowledge of physics, due to the difficulty in transforming the concept. In this paper described how to facilitate this change (transformation concept) use of transformative learning theory. With the transformation of the concept, it is expected to increase metacognitive knowledge, The discussion in this paper provide input for faculty and students in conceptual learning. Discussions focused on developing a theoretical model of learning based on the theory of transformative learning in improving the conceptual knowledge of physics students of LPTK.

\section{REFERENCES}

[1] B. Akarsu, "Einstein's Redundant Triumph "Quantum Physics: An extensive Study of Teaching/Learning Quantum Mechanics in College", in Lat. Am. J. Phys. Educ., Vol. 4, No. 2, May 2010. pp. 273-285, 2010.

[2] B. Joyce et al., Models of Teaching (fourth ed.). Massachusetts: Allyn and Bacon, 1992.

[3] B.F. Bell, Children's Science, Constructivism and Learning in Science, Geelong: Deaken University, 1993.

[4] C. L. Ladera, " Evaluation in physics teaching: make it an opportunity for further learning". in Lat. Am. J. Phys. Educ. Vol. 3, No. 3, 527-534, 2009.

[5] D. F. Styer, "Common Misconceptions Regarding Quantum Mechanics", in American Journal of Physics. Vol. 64 (January 1996), pp. 31-34, 1996.

[6] F.P. Collea, et al., Workshop on Physics Teaching and the Development of Reasoning. New York:American Association of Physics Teachers, 1975.

[7] G. Tsaparlis and G. Papaphotis, " Quantum-chemical Concepts: are They Suitable for Secondary Students?" Chemistry Education: Research and Practice in Europe. Vol. 3, No. 2, pp. 129-144, 2002.

[8] K. Amdani, and M. B. Harahap, Application of Model-Based Learning Approach Applied Systematic Problem Resolution to Improve Ability of Quantum Physics Students Formal Education study program Physics, State University of Medan, The study, funded by the PHKI study program Physics Education. Physics Department, Faculty of Mathematics and Natural Sciences, State University of Medan, Indonesia, Not yet published, 2010.

[9] J. Mezirow, Transformative Dimensions of Adult Learning. San Francisco: Jossey-Bass, 1991.

[10] J. Mezirow, “Transformative Learning:Theory to Practice.” in New Directions for Adult and Continuing Education, no. 74, pp. 5-12, 1997.

[11] K. McGonigal, "Teaching for Transformation: From Learning Theory to Teaching Strategies”. In Speaking of Teaching, Newsletter. Vol. 14, No. 2, 2005.

[12] L.E. Berk, Child Development, Massachusetts: Allyn \& Bacon, 1989.

[13] M. A. Morrison, Understanding Quantum Physics, A User's Manual, USA: Prentice-Hall International Editions, 1990.

[14] M. B. Harahap, Efek Model Pembelajaran Konstruktivis Kognitif-Sosial dan Non-Konstruktivis Konvensional terhadap Hasil Belajar Fisika Dasar Mahasiswa Program S-1 PMIPA LPTK-FKIP Universitas.( Effect of Cognitive-Social Constructivism and Non-Constructivist Conventional Learning Model on Basic Physics Learning Outcomes of 
Students of S-1 Program of PMIPA LPTK-FKIP University). Dissertation: Unpublished, 2005.

[15] M.B. Harahap \& K. Amdani, "Implementasi Model Pembelajaran Terapan Berbasis PSSS dan PSSK untuk Meningkatkan Kemampuan Formal Fisika Kuantum Mahasiswa" (Implementation of Applied Learning Model Based on PSSS and PSSK to Improve Formal Capacity of Quantum Physics Student). in Pedagogik. Vol. 2, No. 2, pp. 89-100, 2007.

[16] M. B. Harahap \& W. Bunawan, Meningkatkan Kemampuan Formal Listrik-Magnet Mahasiswa Program S-1 Prodi Pendidikan Fisika FMIPA Unimed melalui Penerapan Model Pembelajaran AA Berbasis Penyelesaian Soal Secara Sistematis (Improving the ability of Formal Power Magnet Student Program S-1 Faculty of Physical Education Prodi Unimed through AA-Based Learning Model Application Problem Resolution Systematically), The study, funded by the A2 study program Physics Education. Physics Department, Faculty of Mathematics and Natural Sciences, State University of Medan, Indonesia, Not yet published, 2010.

[17] M.B. Harahap. Implementation of transformative learningtheory in improving the conceptual knowledge of physics student of institute ofteachers' education. Aisteel 2016. 395-399
[18] M. de los A. Fanaro, A. Arlego, and M. R. Otero, "A Didactic Proposed for Teaching the Concepts of Electrons and Light in Secondary School Using Feynman's Path Sum Method", in European J of Physics Education Vol. 3, Issue 2, pp. 1-11, 2012.

[19] N. Didis, A. Eryilmaz and S. Erkoc, "Pre-service Physics Teachers' Comprehension of Quantum Mechanical Concepts". in Eurasia Journal of Mathematics, Science \& Technology Education, 2010, Vol. 6, No. 4, pp. 227-235, 2010.

[20] O. Özcan," How do the Students Describe the Quantum Mechanics and Classical Mechanics?", in Lat. Am. J. Phys. Educ. Vol. 4, No. 1, pp. 22 26, 2010.

[21] S. Çalışkan, G.S. Selçuk and M. Erol, "Student Understanding of Some Quantum Physical Concepts”. In Lat. Am. J. Phys. Educ., Vol. 3, No. 2, May 2009. pp. 202-206, 2009.

[22] T. Utomo and K. Ruijter, Peningkatan dan Pengembangan Pendidikan. Jakarta: P. T. Gramedia Pustaka Utama, 1991.

[23] V. Karakostas and A. Hadzidaki," Realism vs. Constructivism in Contemporary Physics: The Impact of the Debate on the Understanding of Quantum Theory and its Instructional Process", in Science \& Education (2005), vol. 14: pp. 607-629, 2005. 